Tropical Journal of Pharmaceutical Research January 2016; 15 (1): 19-26

ISSN: $1596-5996$ (print); 1596-9827 (electronic)

(C) Pharmacotherapy Group, Faculty of Pharmacy, University of Benin, Benin City, 300001 Nigeria.

All rights reserved.

Available online at http://www.tjpr.org

Original Research Article

http://dx.doi.org/10.4314/tjpr.v15i1.3

\title{
Ulmus davidiana var japonica Attenuates Neuroinflammatory Responses in Activated BV2 Murine Microglial Cells via Nuclear Factor-KappaB Signaling Pathway
}

\author{
Hyun-Joo Chang ${ }^{1}$ and Hyun Kang ${ }^{2 *}$ \\ 1Taewoong Food Co., Ltd, 21 Daegeum-ro 196, Daeso-myun, Eumsung-gun, Chungbuk, 27670, ${ }^{2}$ Department of Medical \\ Laboratory Science, College of Health Science, Dankook University, Cheonan-si, Chungnam, 31116, Republic of Korea
}

*For correspondence: Email: hyunbio@gmail.com, hkang@dankook.ac.kr; Tel: 82-41-550-1452; Fax: 82-41-559-7934

Received: 15 September 2015

Revised accepted: 28 December 2015

\begin{abstract}
Purpose: To investigate the antioxidant and anti-inflammatory effects of Ulmus davidiana extract (UDE) in lipopolysaccharide (LPS)-stimulated BV-2 cells.

Methods: Antioxidant activity was measured using 1, 1-diphenyl-2-picryl-hydrazyl (DPPH) radical scavenging assay. Cell viability was evaluated using 3-(4, 5-dimethylthiazol-2-yl)-2, 5-

diphenyltetrazolium bromide (MTT) assay. BV-2 cells were stimulated with LPS to study protein expression and production of inflammatory mediators, and determined by Western blot analysis.

Results: UDE significantly inhibited DPPH-generated free radicals showing maximum inhibition at 40 $\mu \mathrm{g} / \mathrm{mL}(\mathrm{p}<0.001)$. UDE alone did not exhibit any signs of cytotoxicity towards BV-2 cells up to 100 $\mu \mathrm{g} / \mathrm{mL}$ concentration. The LPS-induced increase in the production of nitric oxide was concentrationdependently suppressed with half-maximal concentration (IC $\left.C_{50}\right)$ of $67.4 \mu \mathrm{g} / \mathrm{mL}$ of UDE $(p<0.05$ at 10 $\mu \mathrm{g} / \mathrm{mL}, p<0.01$ at $20 \mu \mathrm{g} / \mathrm{mL}$ and $p<0.001$ at $40 \mu \mathrm{g} / \mathrm{mL}$, respectively). UDE also inhibited dosedependently the LPS-induced increase in inducible nitric oxide synthase (iNOS) and cyclooxygenase-2 $(C O X-2)$ expressions with $I C_{50}$ of $52.3 \mathrm{ug} / \mathrm{mL}$. Furthermore, the production of pro-inflammatory cytokines, via tumor necrosis factor- $\alpha$ by LPS-stimulation in BV2 murine cells was inhibited dosedependently with $I C_{50}$ of $85.1 \mathrm{ug} / \mathrm{mL}$ by UDE pretreatment. Mechanistic studies revealed that UDE acts by regulation of nuclear factor kappa-B signaling pathway in LPS-stimulated BV-2 cells.

Conclusion: This study shows, for the first time, that UDE possesses antioxidant and anti-inflammatory effects and can be developed as a potential therapeutic agent for ameliorating macrophage-mediated inflammation.
\end{abstract}

Keywords: Ulmus davidiana, Anti-oxidant, Anti-inflammatory, iNOS, NF-KB, MCP-1, ERK.

Tropical Journal of Pharmaceutical Research is indexed by Science Citation Index (SciSearch), Scopus, International Pharmaceutical Abstract, Chemical Abstracts, Embase, Index Copernicus, EBSCO, African Index Medicus, JournalSeek, Journal Citation Reports/Science Edition, Directory of Open Access Journals (DOAJ), African Journal Online, Bioline International, Open-J-Gate and Pharmacy Abstracts

\section{INTRODUCTION}

Ulmus davidiana var. japonica (UDE), from the family of Ulmaceae, is widely distributed in Korea, Japan, and China. The stem and root barks of this plant are traditionally used to treat diarrhea, edema, jaundice, hepatitis, and gastric cancer [1]. Its proven medicinal potency merits an elucidation of the mechanisms by which it works and this study will focus on the molecular activities of UDE on BV2 murine microglial cells.

UDE can be used to promote diuresis and to treat dampness [1] It is composed of various 
sesquiterpenes, triterpenes, lignans, and flavonoids [2]. Previous studies have shown that UDE or its isolated components have various effects, including anti-oxidation [2,3], antiinflammatory [3], and possibly anti-angiogenic effect [4].

Neuro-inflammation mediated by microglial activation appears to play an essential role in the pathogenesis of various neuro-degenerative diseases such as Alzheimer's disease, Parkinson's disease and multiple sclerosis [5]. Microglia under activated conditions releases several inflammatory cytokines and toxic free radicals, which may contribute to the neurodegenerative process. Previous reports demonstrate that suppressive agents of the inflammatory mediator concentrations in activated microglia can attenuate the severity of neuro-degenerative diseases [6].

It is well documented that the pathophysiological condition in inflammatory disorders is initiated by a complex processes triggered by microbial endotoxins like LPS, which can directly activate microglia, thus triggering the production of inflammatory mediators, such as NO, COX-2, pro-inflammatory cytokines and leukotrienes [7]. Therefore, LPS-induced inflammatory mediators in vitro can be regarded as one of the essential tools for evaluating the deleterious consequences of excessive activation of microglia. Recent studies have shown that antioxidant and anti-inflammatory agents may suppress microglial activation and thus protect neuronal cell death [8].

In this study, the in vitro antioxidant potential and anti-neuroinflammatory properties of UDE were evaluated in LPS- and interferon- $y$-stimulated BV2 murine microglial cells.

\section{EXPERIMENTAL}

\section{Preparation of $\boldsymbol{U}$. davidiana extract}

Dried plant material of $U$. davidiana purchased from a market specializing in herbs (Traditional herb market; Seoul, Korea). It was authenticated by Prof Chang-Kyu Oh, a taxonomist at Dankook University, South Korea authenticated. A voucher specimen (UD-DKU2015) was stored in Department of Medical Laboratory Science, Dankook University for future reference. To obtain the $U$. davidiana extract, the dried plant material was ground in a blender. The powdered material was extracted with 10 volumes $(\mathrm{v} / \mathrm{w})$ of $70 \%$ ethanol at room temperature for $72 \mathrm{~h}$ and filtered. The residue was extracted with absolute ethanol at 1:10 ratio $(\mathrm{w} / \mathrm{v})$ for $2 \mathrm{~h}$ in a heating mantle at $70-80^{\circ} \mathrm{C}$, and the supernatant was filtered and concentrated in a vacuum evaporator system at $50{ }^{\circ} \mathrm{C}$. For further fractionation, the extract $(1000 \mathrm{mg})$ was partitioned into hexane, chloroform and ethyl acetate (EA) fractions to yield 267, 73 and $307 \mathrm{mg}$, respectively. The active EA fraction of $U$. davidiana (UDE) was redissolved in distilled water.

\section{DPPH radical scavenging activity}

This assay was based on the scavenging of stable 2, 2-diphenyl-1-picrylhydrazyl (DPPH, Sigma-Aldrich, St. Louis, MO, USA) radicals by the radical scavenging antioxidants in UDE. The radical scavenging capacity was evaluated by employing a reaction mixture constituted by aliquots of the UDE and a DPPH methanolic solution as described previously [8]. A sample solution of $60 \mu \mathrm{L}$ of each UDE was added to 60 $\mu \mathrm{L}$ of DPPH $(60 \mu \mathrm{M})$ in methanol. After mixing vigorously for $10 \mathrm{~s}$, the mixture was transferred into a $100 \mu \mathrm{L}$ Teflon capillary tube and the scavenging activity of each sample on DPPH radical was measured using a JES-FA ESR spectrometer (Jeol Ltd., Tokyo, Japan). A spin adduct was measured on an ESR spectrometer exactly after $2 \mathrm{~min}$. Experimental conditions were as follows: central field, $3,475 \mathrm{G}$; modulation frequency, $100 \mathrm{kHz}$; modulation amplitude, $2 \mathrm{G}$; microwave power, $5 \mathrm{~mW}$; gain, $6.3 \times 10^{5}$, and temperature, $298^{\circ} \mathrm{K}$.

\section{Cell cultures and viabilities}

BV2 murine microglia cells were cultured at 37 ${ }^{\circ} \mathrm{C}$ in $5 \% \mathrm{CO}_{2}$ in DMEM (Invitrogen, Carlsbad, CA, USA) supplemented with $5 \%$ Fetal Bovine Serum (FBS, Hyclone, Logan, UT, USA) and antibiotics (Invitrogen). Cell viability was determined by 3-(4, 5- dimethylthiazol-2-yl)-2,5diphenyltetrazolium bromide (MTT) assay as described previously [8]. In all experiments, cells were pre-treated with the indicated concentrations of UDE for $1 \mathrm{~h}$ before the addition of LPS $(1 \mu \mathrm{g} / \mathrm{mL}$, Sigma-Aldrich, St. Louis, MO, USA) in serum free DMEM. An equal volume of sterile water was added to all control treatments. Cells were incubated with various UDE concentrations for $24 \mathrm{~h}$ followed by MTT for $4 \mathrm{~h}$, and then $100 \mu \mathrm{l}$ of isopropanol (in $0.04 \mathrm{~N}$ hydrochloric acid) was added to dissolve the formazan crystals. The absorbance was read at $570 \mathrm{~nm}$ using the Biochrom Anthos 2010 spectrophotometer (Salzburg, Austria). Cell viability was measured by the relative absorbances of the samples compared to the control. 
BV2 murine microglial cells were grown in RPMI1640 (Invitrogen, Carlsbad, CA, USA), supplemented with $10 \%$ FBS (Hyclone, Logan, UT, USA) containing $100 \mathrm{U} / \mathrm{mL}$ of penicillin (Invitrogen), and $100 \mu \mathrm{g} / \mathrm{mL}$ streptomycin (Invitrogen) in $37^{\circ} \mathrm{C}$ in humidified atmosphere of $5 \% \mathrm{CO}_{2}$. In all experiments, cells were pretreated with the indicated concentrations of UDE for $1 \mathrm{~h}$ before the addition of LPS $(1 \mu \mathrm{g} / \mathrm{mL}$, Sigma-Aldrich, St. Louis, MO, USA) in serum free RPMI1640. An equal volume of sterile water was added to all control treatments. Cell viability was determined by 3-(4, 5-dimethylthiazol-2-yl)2,5-diphenyltetrazolium bromide (MTT) assay as described previously [8]. Cells were incubated with various concentrations of UDE for $24 \mathrm{~h}$ followed by MTT for $4 \mathrm{~h}$, and then $100 \mu \mathrm{L}$ of isopropanol (in $0.04 \mathrm{~N}$-hydrochloric acid) was added to dissolve the formazan crystals. The absorbance was read at $570 \mathrm{~nm}$ using the spectrophotometer (Tecan, USA). Cell viability was calculated as relative absorbance compared to control.

\section{Nitric oxide assay}

The amount of stable nitrite, the end product of NO generation, inactivated microglia was determined by a colorimetric assay as previously described [8]. Each supernatant was mixed with the same volume of Griess reagent (1\% sulfanilamide in $5 \%$ phosphoric acid and $0.1 \%$ naphthyl ethylenediamine dihydrochloride in water). The absorbance of the mixture at $540 \mathrm{~nm}$ was determined with an ELISA reader (Bio-Tek Instrument, Winooski, VT, USA). Nitrite concentration was determined by extrapolation from a sodium nitrite standard curve.

\section{Nuclear protein extraction and Western blot analysis}

Cells were washed in cold PBS three times and lysed in a buffer containing $50 \mathrm{mM}$ Tris- $\mathrm{HCl}, \mathrm{pH}$ 7.4, $1 \%$ (v/v) Tergitol- type NP-40 (NP-40), 0.25 $\%$ sodium deoxycholate, $150 \mathrm{mM} \mathrm{NaCl}, 1 \mathrm{mM}$ EDTA, $25 \mathrm{mM} \mathrm{NaF}, 2 \mathrm{mM}$ sodium orthovanadate $\left(\mathrm{Na}_{3} \mathrm{VO}_{4}\right)$ and protease inhibitor cocktail (Complete MiniTM, Roche, Mannheim, Germany) at $4{ }^{\circ} \mathrm{C}$. The lysate was clarified by centrifugation at $10,000 \times \mathrm{g}$ for $20 \mathrm{~min}$ at $4{ }^{\circ} \mathrm{C}$ to remove insoluble components. Cell lysates were normalized for protein content using bicinchoninic acid (BCA) reagent (Pierce, Rockford, IL, USA). Equal amounts of protein were loaded onto $10 \%$ poly acryl amide gel electrophoresis (PAGE) and separated by standard sodium dodecyl sulphate (SDS)-PAGE procedure. Proteins were transferred to an NC membrane (S\&S, Dassel, Germany) and blocked with $5 \%$ non-fat dry milk in TBS. To detect protein expression, the blots were probed with the specific antibodies followed by the secondary antibodies coupled to horseradish peroxidase (Bio-Rad, Herculus, CA, USA) with $\beta$-actin as internal control. The immunoreactive proteins on the membrane were detected by chemiluminescence using the West-Save substrate (Lab-Frontier, Seoul, Korea) on X-ray film. The antibodies against inducible nitric oxide synthase (iNOS), cyclooxegenase (COX) -1, COX-2, nuclear factor kappa-B (NF-kB), I kappa B-alpha (IKB- $\alpha$ ), on extracellular signal-regulated kinase (ERK 1/2) and $\beta$-actin were purchased from Cell (Beverly, MA, USA).

\section{Pro-inflammatory cytokines assay}

Murine BV2 microglia cells $\left(1 \times 10^{5}\right.$ cells/well) were cultured on 96 well plates and treated with the UDE at indicated concentrations for $1 \mathrm{~h}$ and stimulated with LPS $(1 \mu \mathrm{g} / \mathrm{mL})$. At $24 \mathrm{~h}$ post LPS treatment, the production of TNF- $\alpha$ and $1 \mathrm{~h}$ post IFN- $\gamma$ treatment, the production of TNF- $\alpha$ were determined in cell supernatant using assay kits (BD Biosciences, San Jose, CA, USA) as per the manufacturer's instructions. The proinflammatory cytokines assay was performed at room temperature and optical absorbance at 450 $\mathrm{nm}$ was measured using the ELISA reader.

\section{Statistical analysis}

All data are presented as mean \pm S.E.M of at least three independent experiments. Statistical analyses were performed by SAS statistical software (SAS Institute, Cray, NC, USA) using one-way analysis of variance, followed by Dunnett's multiple range tests. $P$-values $<0.05$ were considered statistically significant.

\section{RESULTS}

\section{Effect of UDE on DPPH radical scavenging activity}

As shown in Fig. 1A, UDE exhibited significant DPPH radical scavenging activity in a dosedependent manner, showing a maximum effect at $100 \mu \mathrm{g} / \mathrm{mL}$ of concentration $(p<0.001)$. The ESR spectroscopy data at 10,20, 40,60, 80 and $100 \mu \mathrm{g} / \mathrm{mL}$ are shown in Fig 1B. UDE significantly scavenged the DPPH free radicals.

\section{Effect of UDE on LPS-induced NO production}

UDE treatment did not exhibit any significant cytotoxicity in BV2 murine microglial cells even at a high concentration $(100 \mu \mathrm{g} / \mathrm{ml})$ up to $24 \mathrm{~h}$ of incubation, and in all cases the viability was found above $97 \%$ by MTT assay (Fig 3). 
A

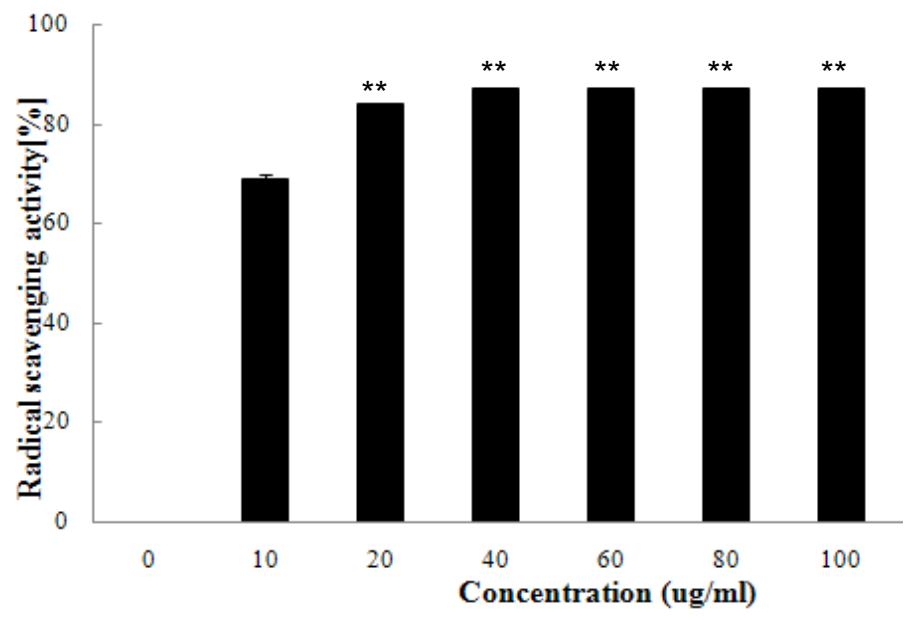

B

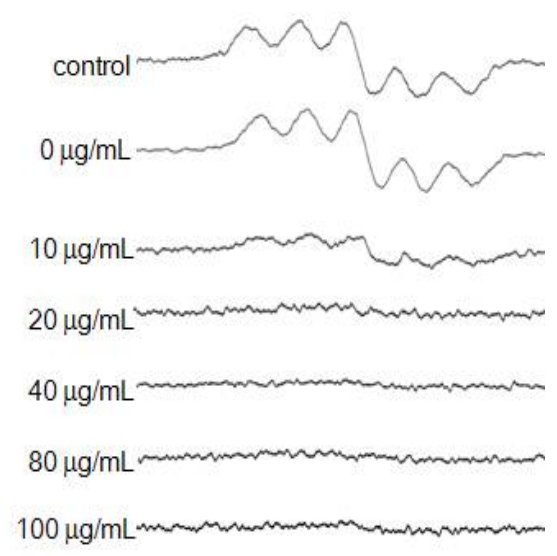

Figure 1: Effect of UDE on DPPH radical scavenging activity on BV2 microglial cells. Data are presented as the mean \pm S.E.M. $(n=3)$ for three independent experiments. ${ }^{* * *} p<0.001$, when compared with control group by one-way analysis of variance, followed by Dunnett's multiple range tests

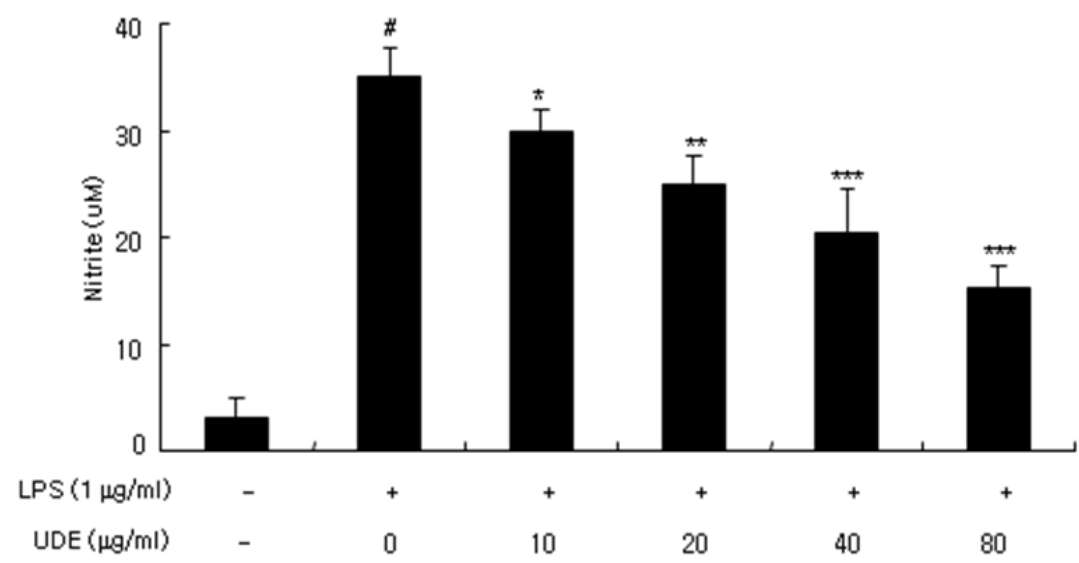

Figure 2: Effect of UDE on NO Production in LPS- stimulated BV2 microglial cells. BV2 cells were treated with UDE at $10,20,40$, and $80 \mu \mathrm{g} / \mathrm{ml}$ with or without LPS $(1 \mu \mathrm{g} / \mathrm{ml})$ for $4 \mathrm{hr}$. Data are presented as the mean \pm SEM $(n=3)$ for three independent experiments. $\# p<0.001$, when compared with control group. ${ }^{*} p<0.05,{ }^{* *} p<0.01$ and ${ }^{* \star *} p<0.001$, when compared with LPS alone treated group by one-way analysis of variance, followed by Dunnett's multiple range tests.

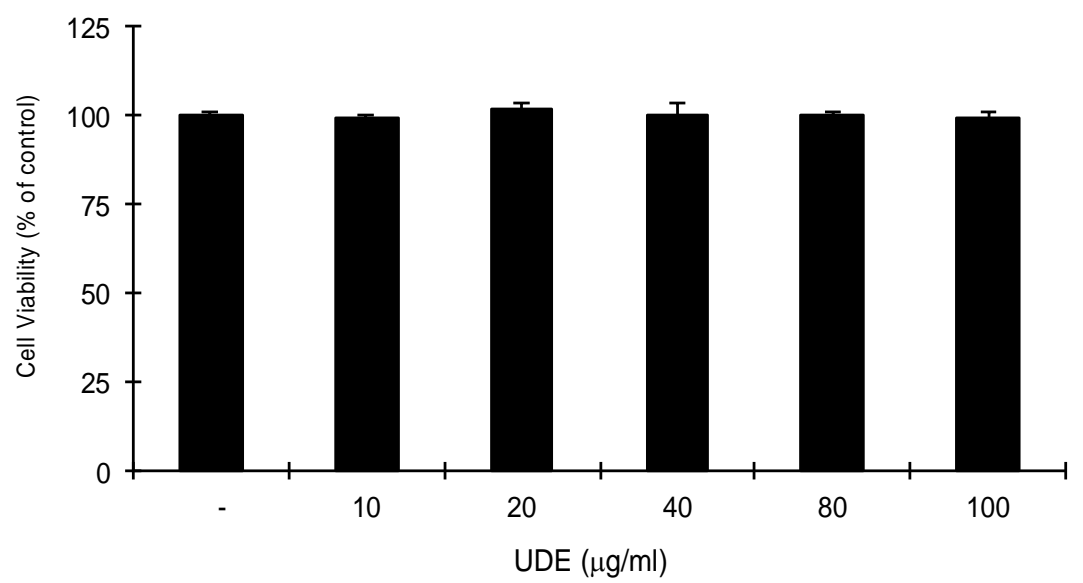

Figure 3: Effect of UDE on the viability of BV2 microglial cells. Data are presented as mean \pm SEM $(n=3)$ for three independent experiments 


\section{Effect of UDE on LPS-induced expression of iNOS and COX levels}

UDE exhibited a broad spectrum of inhibitory effects on the expression of pro-inflammatory mediators. UDE reduced the LPS-stimulated increase of iNOS protein expression and inducible COX-2 in a concentration-dependent manner. This results clearly showed that UDE attenuated LPS-induced iNOS expression and downstream NO production. LPS strongly activates microglia and induces COX-2. Constitutive COX-1 protein expressional levels were uninterrupted (Fig 4).
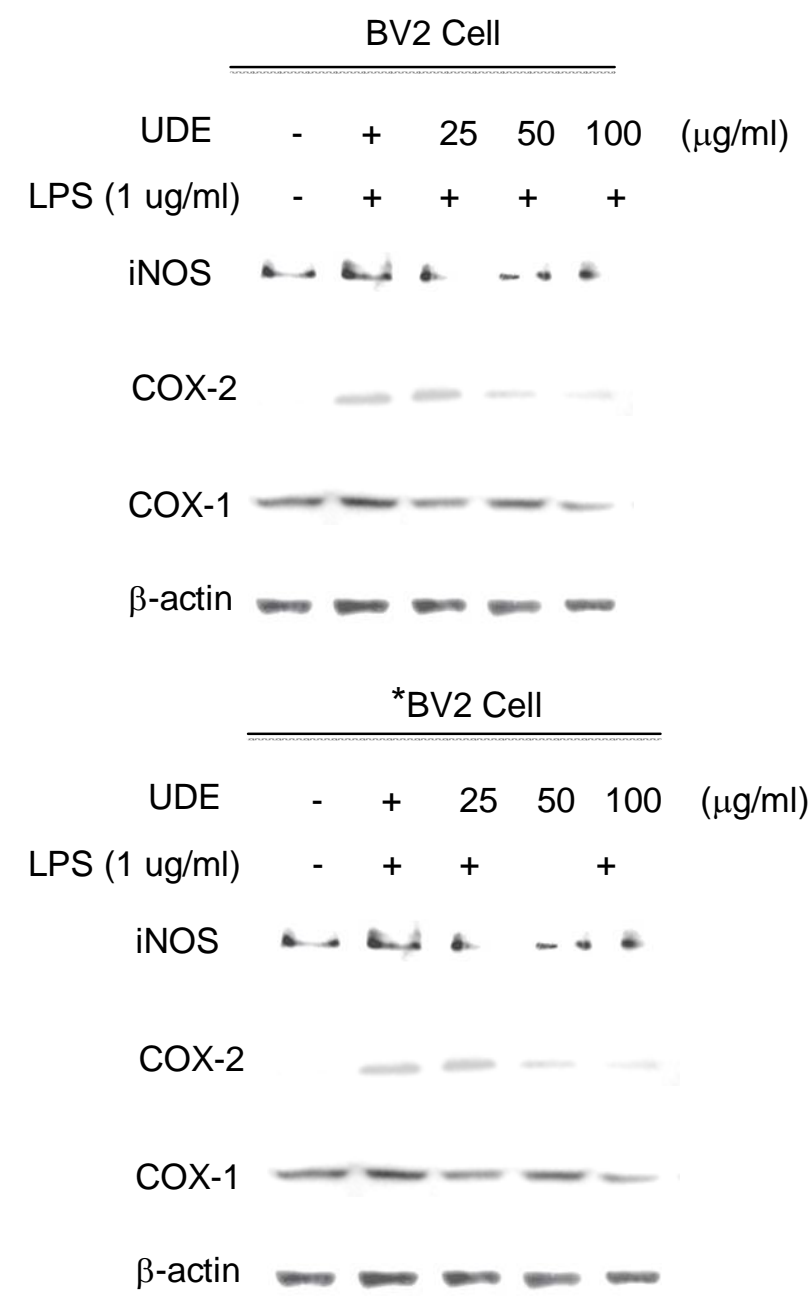

Figure 4: Effect of UDE on iNOS, COX-1 and COX-2 protein expressional levels in LPS-stimulated BV2 microglial cells. The expression levels of iNOS, COX-1 and COX-2 production in the LPS-stimulated BV2 cells at $10,25,50$ and $100 \mu \mathrm{g} / \mathrm{mL}$ of UDE were monitored by immunoblot analyses. The internal control used was $\beta$-actin

\section{Effect of UDE on NF-kB and ERK levels}

UDE inhibited the LPS-induced phosphorylation and degradation of IKB- $\alpha$, and nuclear translocation of $\mathrm{p} 65 \mathrm{NF}-\mathrm{KB}$ in a concentrationdependent manner (Fig. 5). In addition, UDE markedly inhibited the IFN- $\gamma$ induced phosphorylation of ERK after $1 \mathrm{~h}$ stimulation (Fig. 6). These results showed that UDE inhibited LPS-induced phosphorylation/degradation of $\mathrm{IKB} \alpha$ and translocation of NF-KB/p65 sub-unit in a concentration-dependent manner.

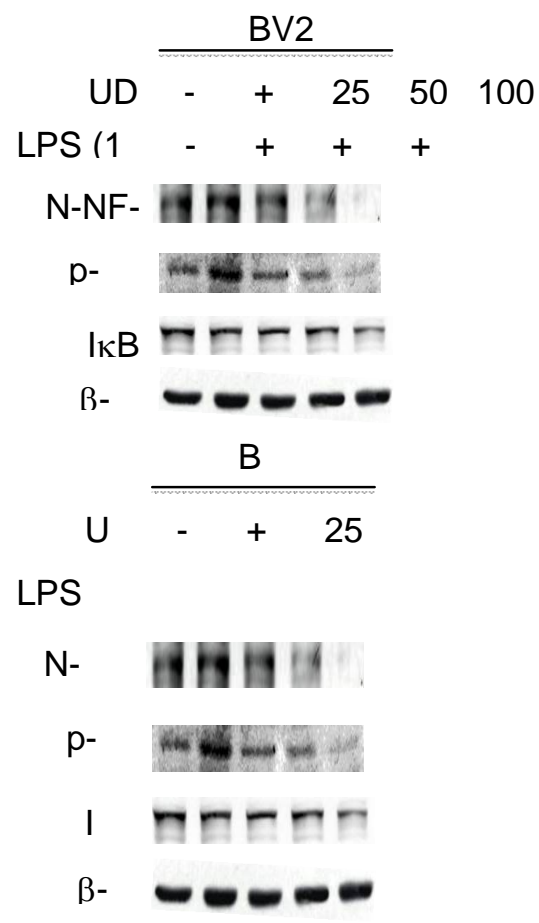

Figure 5: Effect of UDE on nuclear factor-kappaB (NF-KB) activity in LPS- stimulated BV2 microglia. Data is presented as the mean $\pm \operatorname{SEM}(n=3)$ for three independent experiments.

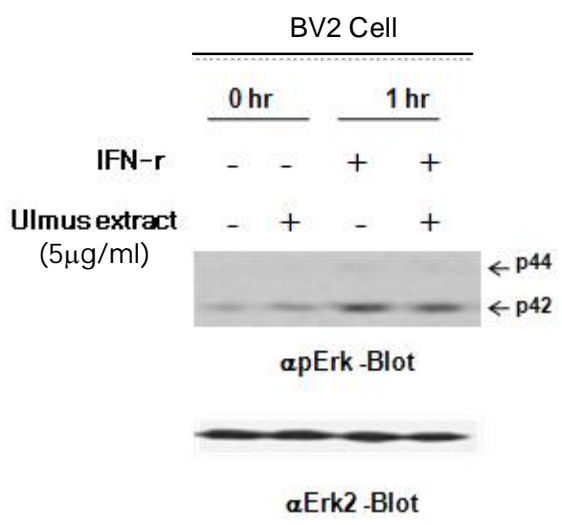

Figure 6: Effect of UDE on extracellular signalregulated kinase (ERK) activity in IFN- $\gamma$ stimulated BV2 microglia. Data are presented as mean \pm SEM $(n=3)$ for three independent experiments 
A

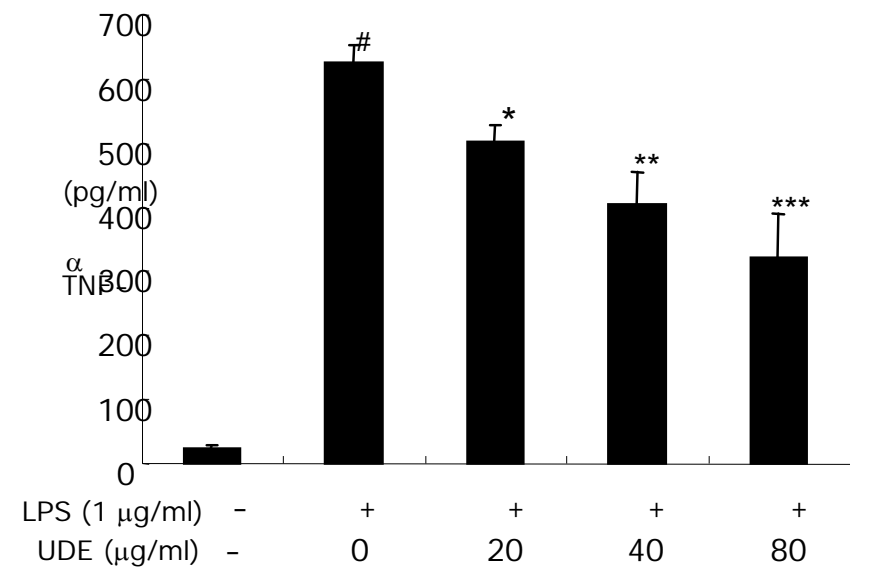

B

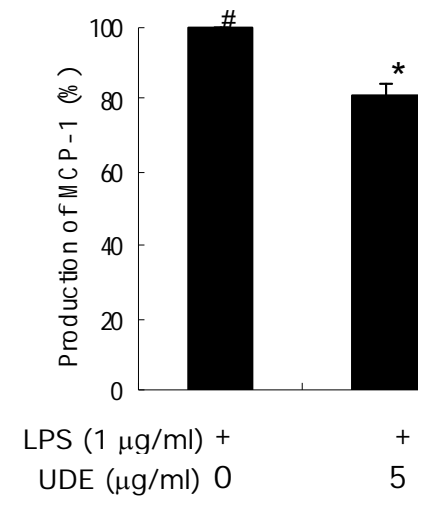

Figure 7: Effect of UDE on pro-inflammatory cytokine TNF-y expression in LPS-stimulated BV2 cells (A). Data is presented as the mean \pm SEM $(\mathrm{n}=3)$ for three independent experiments. $\# p<0.001$, when compared with control group. ${ }^{*} p<0.05,{ }^{* *} p<0.01,{ }^{* * *} p<0.001$, compared with LPS only group; comparison made by one-way analysis of variance, followed by Dunnett's multiple range tests. Effect of UDE on pro-inflammatory cytokine MCP-1 expression in IFN- $\gamma$ stimulated BV2 cells $(B)$. Data is presented as the mean \pm SEM $(n=3)$ for three independent experiments

\section{Effect of UDE on TNF-aproduction in LPS- stimulated BV2 cells}

LPS stimulation of the BV2 murine microglial cells increased TNF- $\alpha$ expression. However, pretreatment with UDE decreased the LPSinduced TNF- $\alpha$ level in BV2 microglia (Fig. 7A). Pro-inflammatory cytokines such as TNF- $\alpha$, IL-1 $\beta$ and IL- 6 caused potent activation of iNOS gene expression in rodent glial cells and muscle cells [11]. The likelihood of the involvement of UDE in attenuating such factors is supported by this observations that pro-inflammatory mediator TNF- $\alpha$ produced by LPS treatment was suppressed by UDE in BV2 microglial cells indicating that UDE may be an effective antineuroinflammatory agent.

\section{Effect of UDE on MCP-1production in IFN-y stimulated BV2 cells}

Monocyte Chemo-attractant Protein-1 (MCP-1) is the first discovered and most extensively studied $\mathrm{CC}$ chemokine, and the number of studies on the etiologies of obesity and diabetes-related diseases has increased exponentially in the past two decades [12]. The roles of MCP-1 in the development of obesity, diabetes and cardiovascular diseases in metabolically healthy problems [12]. IFN- $\gamma$ stimulation increased MCP1 expression in BV- cells, while pretreatment with UDE decreased the LPS-induced MCP-1 levels in BV2 microglia (Fig. 7B).

\section{DISCUSSION}

Inflammation is partially ascribed to release of toxic free radicals and ROS. DPPH radical scavenging assay is one of the widely used methods for screening the free radical scavenging activities of several agents in a relatively short period of time. In the present study, AEE significantly scavenged the DPPH free radicals. In this study a pro-inflammatory stimulus by LPS on BV2 cells resulted in excessive production of NO. NO production by LPS-activated cells was significantly inhibited by UDE in a concentration-dependent manner.

Excessive production of inflammatory mediators such as nitric oxide (NO), prostaglandin E2 (PGE2), and proinflammatory cytokines, including tumor necrosis factor-alpha (TNF- $\alpha$ ) and interleukin-1beta (IL-1 $\beta$ ) from activated microglia contributes to uncontrolled inflammation in neurodegenerative diseases. It seems possible that treatment with antiinflammatory agents, including plants used in Oriental medicine, might delay the progression of neurodegeneration through the inhibition of microglial activation [9]. These results indicated that UDE significantly inhibited the excessive production of NO, in LPS-stimulated BV2 cells.

It was well known that COX-1 is constitutively expressed in many cell types and COX-2 is normally not present in most cells, but its expression is induced in response to inflammatory cytokines linked to pathological 
events [10]. Earlier literature revealed that increased expression of the COX-2 plays an important role in the inflammatory process and neuro-degenerative diseases [10]. Several reports indicate that iNOS and COX-2 are induced excessively in various types of central nervous injuries and diseases [10]. Attenuation of the induction of iNOS and COX-2 in activated microglia can prevent neuro-inflammation. Although this results point to a potential role of UDE in inhibiting iNOS and COX-2 production, the possibility remains that UDE may further suppress other microglia-derived proinflammatory factors upon LPS treatment in BV2 cells.

Pro-inflammatory cytokines such as TNF- $\alpha$, IL$1 \beta$, and IL- 6 play central roles in inflammation. In particular, increased levels of brain TNF- $\alpha$ and IL-6 has been associated with severe cognitive impairments, neuronal damage and neuroinflammation [13]. Therefore, the effects of UDE on pro-inflammatory cytokine TNF- a production in LPS-stimulated BV2 cells were evaluated. LPS-stimulation increased the levels of TNF- $\alpha$ in BV2 cells. However, pretreatment with UDE suppressed the increased TNF- $\alpha$ production indicating that AEE may convincingly be an effective anti-inflammatory agent.

NF-KB, a mammalian transcription factor, activated by LPS, is known to control the expression of cell survival genes as well as proinflammatory enzymes and cytokines [14].

The molecular mechanisms that underlie UDEmediated attenuation are related to the inhibition of the phosphorylation of three mitogen-activated protein kinases (MAPKs), extracellular signalregulated kinases 1 and 2 (ERK1/2), p38 MAPK, and c-Jun $\mathrm{N}$-terminal kinase (JNK), and the activation of nuclear factor-kappaB (NF-kB). Our result showed that $A E E$ inhibited the LPS induced phosphorylation/degradation of IKB- $\alpha$ and translocation of NF-KB/p65 sub unit in a concentration-dependent manner. Considering the above data, we can conclude that NF-KB is a major target of UDE. However, the exact molecular target of UDE on NF-KB activation remains to be elucidated.

\section{CONCLUSION}

The findings of this study indicate that UDE inhibits anti-inflammatory responses via NF-KB signaling in LPS-stimulated BV2 murine cells. Further, the antioxidant activity of UDE may be partly involved in the observed effects.

\section{ACKNOWLEDGEMENT}

This work was supported by the Technological Innovation R\&D Program (S2222532) funded by the Small and Medium Business Administration (SMBA, Republic of Korea).

\section{REFERENCES}

1. Hong ND, Rho YS, Kim NJ, Kim JS. A study on efficacy of Ulmi cortex. Kor J Pharmacogn 1990; 21: 217-222.

2. Lee MK, Kim YC. Five novel neuroprotective triterpene esters of Ulmus davidiana var. japonica. J Nat Prod 2001; 64: 328-331.

3. Jun $C D$, Pae HO, Kim YC. Inhibition of nitric oxide synthesis by butanol fraction of the methanol extract of Ulmus davidiana in murine macrophages. $J$ Ethnopharmacol 1889; 62: 129-135.

4. Jung HJ, Jeon HJ, Lim EJ. Anti-angiogenic activity of the methanol extract and its fractions of Ulmus davidiana var. japonica. J Ethnopharmacol 2007; 112: 406-409.

5. Perry VH, Gordon S. Macrophages and microglia in the nervous system. Trends Neurosci 1988; 11: 273- 277.

6. Liu B, Hong JS. Role of microglia in inflammationmediated neurodegenerative diseases: mechanisms and strategies for therapeutic intervention. J Pharmacol Exp Ther 2003; 304: 1-7.

7. Xie QW, Kashiwabara $Y$, Nathan C. Role of transcription factor NF-kappa B/Rel in induction of nitric oxide synthase. J Biol Chem 1994; 269: 4705-4708.

8. Agullo G, Gamet-Payrastre L, Manenti $S$, Viala $C$, Rémésy $C$, Chap H, Payrastre B. Relationship between flavonoid structure and inhibition of phosphatidylinositol 3-kinase: a comparison with tyrosine kinase and protein kinase C inhibition. Biochem Pharmacol 1997; 53: 2087-2094.

9. An HJ, Seo MJ, Choi IY, Park RK, Jeong S, Lee JY, Kim HM, Um JY, Hong SH. Induction of nitric oxide \& tumour necrosis factor- $\alpha$ by Psoralea corylifolia. Indian J. Med. Res 2008; 128: 752-758.

10. Teismann $P$, Vila $M$, Choi $D K$, Tieu $K, W u D C$, JacksonLewis V, Przedborski S. COX-2 and neurodegeneration in Parkinson's disease. Ann NY Acad Sci 2003; 991: 272-277.

11. Hunot S, Hartmann A, Hirsh EC. The inflammatory response in the Parkinson brain. Clin Neurosci Res 20011: 434-443.

12. Coughlan CM, McManus CM, Sharron M, Gao Z, Murphy $D$, Jaffer $S$. Expression of multiple functional chemokine receptors and monocyte chemoattractant protein-1 in human neurons. Neuroscience 2000; 97: 591-600.

13. Kim BW, Koppula S, Kim IS, Lim HW. Antineuroinflammatory activity of Kamebakaurin from Isodon japonicus via inhibition of c-Jun NH-terminal kinase and p38 mitogen-activated protein kinase pathway in activated cells. J Pharmacol Sci 2011; 116: 296-308. 
14. Tuttolomondo A, Di Raimondo $D$, di Sciacca $R$, Pinto $A$, Licata G. Inflammatory cytokines in acute ischemic stroke. Curr Pharm Des. 2008; 14: 3574-3589. 